\title{
The Effect of Corporate Life Cycle on Financial Reporting Quality Companies Listed in Tehran Stock Exchange
}

\author{
Vahid Khosravi Zadband ${ }^{1}$, Hamed Omrani ${ }^{2}$ \\ Islamic Azad University, Neyshabur Branch, Iran \\ Zadband@gmail.com \\ Ph.D Student in Accounting, University of Tehran, Iran \\ Omrani86@gmail.com
}

\begin{abstract}
The major purpose of the current study was to investigate the effect of corporate life cycle on financial reporting quality of companies listed in Tehran Stock Exchange. Therefore, accruals quality and volume of abnormal accruals were utilized as measures to evaluate financial reporting quality. First, the statistical population was separated into firms at growth, maturity and decline stages using variables such as sales growth, dividend per share, capital expenditure and corporate age and then the hypotheses were tested via multiple-variable regression equations and mean comparison test. Results of studying 110 firms (1320 firms-years) during the time period 2002-2013 indicated that degrees of financial reporting quality in different stages of corporate life cycle (growth, maturity and decline) have a significant difference with each other. According to results of mean comparison test, financial reporting quality is at the highest level in maturity stage and at the lowest level in growth stage.
\end{abstract}

Keywords: corporation; investigate; Corporate; Stock Exchange; Quality

\section{Council for Innovative Research}

Peer Review Research Publishing System

Journal: International Journal of Management \& Information Technology

Vol. 9, No. 2

editor@cirworld.com

www.cirworld.com, member.cirworld.com 


\section{INTRODUCTION}

Providing the necessary grounds for optimal allocation of resources is the major role of accounting information in financial markets. Investors' trust in financial reporting system has been attenuated due to recent financial scandals and financial reporting quality is regarded as an important factor in determining the credit and reliability of figures. Consequently, investors, managers, lawmakers and devisers of standards are interested in determining the quality of accounting information and the obtained results. In recent years, financial analysts, managers, and investors have paid much attention to profitability report of firms (Karami \& Omrani, 2011).

Financial reporting quality can affect the investors' trust in financial markets. Various methods of accounting, the current deficiencies in the process of estimations and predictions, managers' authority, influence of reporting principles on profit and managers' discretion can be mentioned among the important effective factors on financial reporting quality. The term financial reporting quality refers to ability of managers in utilization of optional items for profit measurement and reporting. Optional items may include choosing among the principles or standards of accounting and utilization of estimations and scheduling the transactions to identify abnormal items (Karami \& Omrani, 2011). Researchers have discussed about financial reporting quality during the three recent decades and it has been tried to evaluate financial reporting quality through achieving a logical and reliable method and identify the effective factors on it (Desai et al., 2009).

Life cycle stages of business units are divided differently in theories of economy and management. In the related literature, several models with some stages have been proposed in which corporations and firms follow a specific policy given to each stage of their economic life. These policies are reflected in accounting information of firms (Khosravi, 2010). Researches conducted in other countries such as Anthony and Ramesh (1992), Black (1988), Aharoni et al. (2003), and Xu (2007) indicate the important effect of life cycle on accounting variables. Financial reporting quality is one of the most important accounting information. Thus, the major purpose of the current study is to investigate the effect of corporate life cycle on financial reporting quality of firms.

\section{LIFE CYCLE THEORY OF FIRMS}

All creatures such as plants, animals and human beings follow life cycle curve. These creatures are born, grown, aged and finally they die. Living systems have special behavioral models in any stage of their life in order to dominate issues of that period and problems of transferring from one period to another (Adizes, 1989). Scholars of economic and management sciences have conducted studies about life cycle of for-profit corporations and firms and have divided life cycles into some stages. Models with several stages have been proposed for life cycle in the related literature. In the framework of such models, firms follow a specific policy given to each stage of their economic life. The policies are reflected in accounting information of firms (Khosravi, 2010). In accounting field, researchers such as Anthony and Ramesh (1992), Black (1988) and Aharoni et al. (2003) have investigated the effect of life cycle on accounting information. They have explained four stages for life cycle curve as below:

1- Birth stage

2- Growth stage

3- Maturity stage

4- Decline stage

In birth stage, properties of the firm are usually at a moderate level; cash flow of operational activities and productivity are low and firms need a high liquidity for financing and realization of growth opportunities. Coefficient of cash dividend in such firms is usually equal to zero or at most $10 \%$ and return on investment in comparison with the weighted rate of financing is normally insignificant (Karami \& Omrani, 2011).

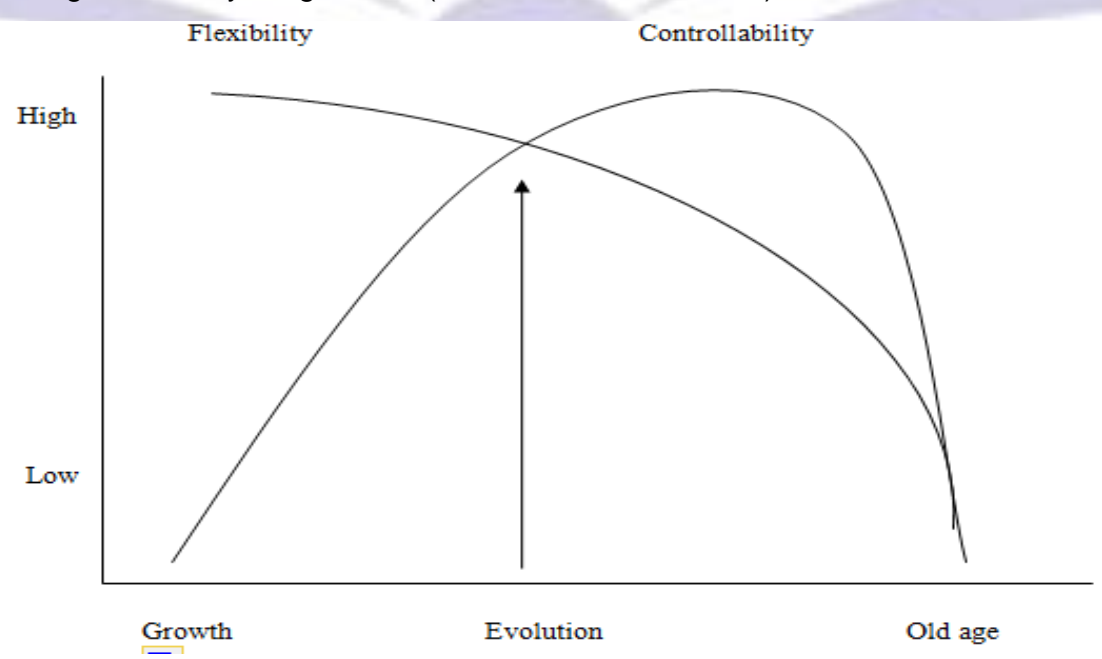

Diagram 1. Relationship between flexibility and controllability in life cycle of business units 
Firms in growth stage have a larger size than those in birth stage. Financial resources are invested more in facilities and equipments (productive assets) and liquidity indexes have a suitable status; coefficient of cash dividend in such firms is usually between 10 and 50 percent. Return on investment is often more than the weighted rate of cost of capital (Karami \& Omrani, 2011). In the maturity stage, firms experience a stable and balanced rate of sales growth and the need to cash is often satisfied via domestic resources. Properties of firms in this stage are more than those in growth stage and coefficient of cash dividend in such firms usually fluctuates between 50 and 100 percent. Due to abundance of liquidity and reduced reliance on financing policy from outside of the firm, return on investment in these firms is generally equal to weighted rate of cost of capital or more than it (Karami \& Omrani, 2011). If there are growth opportunities in decline stage, most probably they will be very insignificant. Indexes of profitability, liquidity and commitment have a descending order and the firm is exposed to highly competitive conditions; besides, financing cost of financial resources is high due to borrowing from external resources. Thus, return on investment in most cases is less than the financing rate (Karami \& Omrani, 2011).

In this study the companies were separated into three forms of firms in growth, maturity and decline stages because of lack of stock exchange of newly-established companies.

\section{RESEARCH BACKGROUND}

Anthony and Ramesh (1992) classified the firms into life cycle stages (growth, maturity, and decline) and investigated the relationship between accounting variables (sales growth, capital expenditure, and cash dividend) and stock exchange price. Their findings revealed that there is a significant relationship among accounting variables and stock exchange price in different life cycle stages. Black (1998) studied and compared the relationship between profit and cash flows with corporate value in the framework of life cycle model. In this survey, life cycle was considered as a key for finding a stronger accounting measure. The hypotheses were completed in order to predict the more relevant value in each stage of life cycle. According to results of this survey, cash flows are more relevant than profit in birth and decline stages and the profit is more relevant than cash flows in the maturity stage.

In another study, Anthony and Ramesh (1992) classified companies into growth, maturity and decline stages and studied the effect of life cycle on information content of components of earnings_and cash flows obtained from operations in predicting the covering ratio of "market value to stock return". Their findings revealed that information content of the model based on operating cash flows in birth and growth stages is more than that of the model based on earnings. Moreover, the opposite of it is true in decline and maturity stages. Aharoni et al. (2003) investigated which measures of cash flows and accruals are more relevant and can explain market value of the firm better. The results demonstrated that both measures (based on cash flows and accruals) have relevant value but explanatory powers of these two measures have a significant difference with each other in different stages of life cycle. Hence, explanatory power of measures based on cash flows in growth stage is higher and the opposite is true in maturity and decline stages. Park and Chen (2006) investigated the effect of conservatism on investors' reaction towards net operating assets and abnormal operating profit in different stages of life cycle using Feltham and Olson's model (1995). Results of investigating 8328 firms-years during the time period 1982-1993 show that net operating assets and abnormal operating profit of firms in growth stage are more important for investors than net operating assets and abnormal operating profit of firms in maturity and decline stages. Similarly, the results indicate that net operating assets and abnormal operating profit of conservative firms are more important for investors than firms which utilize aggressive accounting practices. The opposite of this is true in decline stage. Xu (2007) studied the effect of corporate life cycle on relevance of risk standards during the time period 1991-2004 and the statistical population was consisted of 15706 firms-years. They were separated into growth, maturity and decline stages through variables such as ratio of stock return payment, sales growth, ratio of capital expenditures and corporate age. Therefore, 5218, 5226 and 5262 firms were considered in growth, maturity and decline stages respectively. The results showed that relevance degree as well as the increasing explanatory power of risk standards in different stages of life cycle has a significant difference. Increasing explanatory power of risk standards in decline stage has the highest value; while it has the lowest value in maturity stage. In a study entitled dividend policy and life cycle theory, Wang (2009) investigated dividend policy and life cycle theory. The obtained results demonstrated that paying the stock return in newlyestablished business units with high capability of growth and low profitability is led to dividend distribution in the form of dividend per share than cash dividend. When business units are matured, low capability of growth and high profitability are led to more distribution of cash dividend against dividend per share. Thanatawee (2011) studied the assumption regarding free cash flow and life cycle theory in Thailand. Having subtracted essential funds for investment, he used the cash flow obtained from operational activities to test free cash flow assumption. Also, he used ratio of retained profit to book value of return on equity to test the life cycle theory. The results of this study revealed that there is a positive and significant relationship among free cash flow, life cycle stages and dividend policy.

\section{HYPOTHESES}

In order to evaluate financial reporting quality in this study, two indexes including accruals quality and volume of abnormal accruals were used according to Rajgopal and Venkatachalm's survey (2011). The hypotheses have been proposed as the following.

Primary hypothesis: Degrees of financial reporting quality in different stages of life cycle (growth, maturity and decline) have a significant difference with each other.

Secondary hypothesis 1 : Values of accruals quality in different stages of life cycle (growth, maturity and decline) have a significant difference with each other. 
Secondary hypothesis 2: Volumes of abnormal accruals in different stages of life cycle (growth, maturity and decline) have a significant difference with each other.

\section{METHODOLOGY}

Inductive and ex-post facto method (using past information) was used to conduct the present study and the statistical method was cross-sectional correlation, i.e. studying whether or not there is any relationship among the variables through regression. The collected data was analyzed in two stages. In the first stage, each member of the statistical population was classified into growth, maturity and decline stages using separator variables and in the second stage, the hypotheses were tested via statistical techniques of correlation analysis, multi-variable regression and Wang's statistical test.

\subsection{Classification of firms into life cycle stages}

Anthony and Ramesh (1992) used four variables of sales growth, capital expenditure, dividend per share and corporate age in order to separate the firms. Separation of firms into growth, maturity and decline stages using the above four variables and based on Park and Chen's methodology (2006) has been explained in the following:

1. First, value of each variable of sales growth, capital expenditure, dividend per share and corporate age is calculated for each firm-year.

2. Firms-years are divided into five classes based on the above variables and via statistical quantiles in any industry. A score from 1 to 5 is allocated to them given to their status in the intended class according to Table 1.

3. Then a composite score is obtained for each firm-year that is classified into one of the growth, maturity and decline stages considering the following conditions:
A. If sum of scores is between 16 and 20, it is at the growth stage.
B. If sum of scores is between 9 and 15 , it is at the maturity stage.
C. If sum of scores is between 4 and 8 , it is at the decline stage.

Table 1. Model of corporate life cycle ${ }^{1}$

\begin{tabular}{|l|c|c|c|c|}
\hline Classes & Corporate age & $\begin{array}{c}\text { Sales growth } \\
\text { (SG) }\end{array}$ & $\begin{array}{c}\text { Capital expenditures } \\
\text { (CE) }\end{array}$ & $\begin{array}{c}\text { Dividend per share } \\
\text { (DPS) }\end{array}$ \\
\hline Class 1 & 5 & 1 & 1 & $5(1)^{1}$ \\
\hline Class 2 & 4 & 2 & 2 & $4(2)^{2}$ \\
\hline Class 3 & 3 & 3 & 4 & 3 \\
\hline Class 4 & 2 & 4 & 5 & 3 \\
\hline Class 5 & 1 & 5 & 4 & 3 \\
\hline
\end{tabular}

Operational definition of the above variables is as follows:

$S G_{i t}=\left[\left(\right.\right.$ Sale $_{i t} /$ Sale $\left.\left._{i t-1}\right)-1\right] \times 100$

$\mathrm{DPR}_{\text {it }}=\left(\mathrm{DPS}_{\mathrm{it}} / \mathrm{EPS}_{\mathrm{it}}\right) \times 100$

$\mathrm{CE}_{\mathrm{it}}=($ corporate market value/excessive (reduced) fixed assets during the time period) $\times 100$

Sale $=$ sales revenue

DPS= dividend per share

EPS= earnings per share

\footnotetext{
${ }^{1}$ Value of dividend per share is relatively low in firms in growth stage due to growth opportunities and high investment in capital assets as well as firms in decline stage due to the liquidity problems. Thus, low value of dividend per share can illustrate that the firm is in growth or decline stage. If sum of scores of three variables including sales growth, capital expenditures and age is less than 3 and score of dividend per share is equal to 4 (or 5), the score equal to 2 (or 1 ) is used instead.
} 
AGE=difference between the firm's year of establishment and year $t$

\subsection{Research model}

In order to evaluate financial reporting quality in this study, two indexes including accruals quality and volume of abnormal accruals were used for firms at different stages of life cycle according to Rajgopal and Venkatachalm's survey (2011). Financial reporting quality $(R Q)$ is measured based on error terms of the following models:

- The first regression model: based on accruals quality

$$
T C A_{\text {it }}=\varphi_{0}+\varphi_{1} \mathrm{CFO}_{\text {it }-1}+\varphi_{2} \mathrm{CFO}_{\text {it }}+\varphi_{3} \mathrm{CFO}_{\text {it }+1}+\varphi_{4} \Delta \mathrm{REV}_{\text {it }}+\varphi_{5} \mathrm{PPE}_{\text {it }}+v_{\text {it }}
$$

- The second regression model: based on volume of abnormal accruals

$$
T A_{i t}=\delta_{0}+\delta_{1}\left(\Delta R E V_{i t}-\Delta A R_{i t}\right)+\delta_{2} P P E_{i t}+\delta_{3} R O A_{i t}+\eta_{i t}
$$

Then significance of difference of financial reporting quality indexes (accruals quality and volume of abnormal accruals) were studied in growth, maturity and decline stages by means of $F$ test (mean comparison of several statistical populations).

\subsection{Statistical population and statistical sample}

Statistical population of the current study included companies listed in Tehran Stock Exchange during the time period 2002-2013. Sample size was selected using sampling method and given to the following conditions:

1- The intended company should not be among the investment, intermediary and holding companies.

2- End of the fiscal year should be March 20 for comparability.

3- Financial information of companies should be accessible in the period under study.

4- At least three years should be expired since the beginning of the company's activity as a public company because companies whose work experience is less than three years are regarded as newly-established and are not considered in classification of companies in terms of life cycle (Dehdar, 2008).

\subsection{Descriptive statistics of data}

Table 3 shows descriptive statistics of independent and dependent variables as well as the variables used for classification of firms into life cycle stages including growth, maturity and decline stages. The whole observations were equal to 1320 firms-years (110 firms) after omitting the unrelated data and 324, 588 and 408 firms-years were considered in growth, maturity and decline stages respectively. As it is observed, there is an extensive deviation among descriptive statistics of variables at various levels of corporate life cycle. Mean value of sales growth and capital expenditure has a descending order from growth to decline stages. Firms in the growth stage have the highest mean of sales growth (0.653) and capital expenditure $(0.161)$ and firms in decline stage have the lowest mean of sales growth (0.091) and capital expenditure (0.051). Generally, results of Table 3 are consistent with our expectations from financial characteristics of firms at different stages of life cycle based on Table 2.

\begin{tabular}{|c|c|c|c|c|c|c|}
\hline \multirow[t]{2}{*}{ Variable } & \multicolumn{2}{|c|}{$\begin{array}{l}\text { Growth stage } \\
\qquad(n=324)\end{array}$} & \multicolumn{2}{|c|}{$\begin{array}{l}\text { Maturity stage } \\
\qquad(n=588)\end{array}$} & \multicolumn{2}{|c|}{$\begin{array}{l}\text { Decline stage } \\
\qquad(\mathrm{n}=408)\end{array}$} \\
\hline & Mean & $\begin{array}{l}\text { Standard } \\
\text { deviation }\end{array}$ & Mean & $\begin{array}{l}\text { Standard } \\
\text { deviation }\end{array}$ & Mean & $\begin{array}{l}\text { Standard } \\
\text { deviation }\end{array}$ \\
\hline Constant coefficient & 1.312 & 6.972 & 0.824 & 4.612 & 1.023 & 1.612 \\
\hline Accruals quality & 1.242 & 4.675 & 2.561 & 3.782 & 1.982 & 2.965 \\
\hline Sales growth & 0.653 & 8.434 & 0.387 & 16.786 & 0.091 & 3.897 \\
\hline Dividend per share & 0.149 & 7.461 & 0.328 & 24.573 & 0.175 & 8.342 \\
\hline Capital expenditure & 0.161 & 13.126 & 0.092 & 13.678 & 0.056 & 6.231 \\
\hline Age & 9 & 10.52 & 17 & 13.84 & 28 & 8.25 \\
\hline
\end{tabular}

Table 3. Descriptive statistics of data 


\subsection{The utilized models and testing of hypotheses}

Before estimating the goodness of regression models on the basis of accruals quality and volume of abnormal accruals, it is essential to test the assumptions of linear regression. Results obtained from Kolmogoroff-Smirnoff test indicate normality of distribution of the dependent variable; Durbin-Watson test shows independence of errors and VIF test reveals nonexistence of co-linearity among the independent variables.

Results of goodness of regression models (1) and (2) by separation of life cycle stages are displayed in Table 5. As it is observed, $F$ statistics reveal significance of all regression models and results of Durbin-Watson test show independence of errors.

Table 5. Results of goodness of regression models (1) and (2)

\begin{tabular}{|c|c|c|c|c|c|c|c|c|c|c|}
\hline \multicolumn{11}{|c|}{$T C A_{\text {it }}=\varphi_{0}+\varphi_{1} C F 0_{\text {it }-1}+\varphi_{2} C F 0_{i t}+\varphi_{3} C F 0_{\text {it }+1}+\varphi_{4} \Delta R E V_{i t}+\varphi_{5} P P E_{i t}+v_{\text {it }}$} \\
\hline \multirow{2}{*}{\multicolumn{2}{|c|}{ Variables }} & \multicolumn{3}{|c|}{ Growth stage } & \multicolumn{3}{|c|}{ Maturity stage } & \multicolumn{3}{|c|}{ Decline stage } \\
\hline & & $\begin{array}{l}\text { Value of } \\
\text { coefficient }\end{array}$ & t-statistic & P-value & $\begin{array}{l}\text { Value of } \\
\text { coefficient }\end{array}$ & t-statistic & P-value & $\begin{array}{l}\text { Value of } \\
\text { coefficient }\end{array}$ & t-statistic & P-value \\
\hline \multirow{8}{*}{ 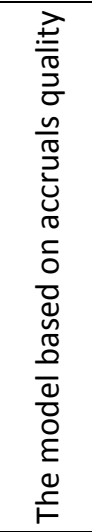 } & $\begin{array}{c}\text { Constant } \\
\text { coefficient }\end{array}$ & 2.636 & 4.341 & 0.000 & 2.355 & 2.871 & 0.001 & 2.315 & 3.121 & 0.001 \\
\hline & $\mathrm{CFO}_{\mathrm{t}-1}$ & 0.979 & $2 / 201$ & $0 / 040$ & 0.691 & $2 / 362$ & $0 / 023$ & 0.438 & $2 / 306$ & $0 / 024$ \\
\hline & $\mathrm{CFO}_{\mathrm{t}}$ & 0.871 & $2 / 062$ & $0 / 028$ & 0.332 & $2 / 197$ & $0 / 032$ & 0.233 & $2 / 631$ & $0 / 010$ \\
\hline & $\mathrm{CFO}_{\mathrm{t}+1}$ & 0.962 & $2 / 59$ & $0 / 021$ & 0.601 & $3 / 106$ & $0 / 003$ & 0.321 & $1 / 324$ & $0 / 187$ \\
\hline & $\triangle \mathrm{REV}$ & $0 / 065$ & $1 / 895$ & $0 / 062$ & $0 / 102$ & $3 / 654$ & $0 / 001$ & $0 / 212$ & $-1 / 402$ & $0 / 166$ \\
\hline & PPE & $1 / 842$ & $-3 / 421$ & $0 / 001$ & $2 / 151$ & $3 / 009$ & $0 / 004$ & $5 / 201$ & $-3 / 536$ & $0 / 01$ \\
\hline & $R^{2} \quad$ Adjusted & \multicolumn{3}{|c|}{$37 \%$} & \multicolumn{3}{|c|}{$21 \%$} & \multicolumn{3}{|c|}{$43 \%$} \\
\hline & F-statistic & \multicolumn{2}{|r|}{10.347} & & \multicolumn{3}{|c|}{8.793} & \multicolumn{3}{|c|}{13.318} \\
\hline \multirow{7}{*}{ 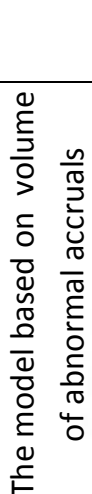 } & & \multicolumn{9}{|c|}{$T A_{i t}=\delta_{0}+\delta_{1}\left(\Delta R E V_{i t}-\Delta A R_{i t}\right)+\delta_{2} P P E_{i t}+\delta_{3} R O A_{i t}+\eta_{i t}$} \\
\hline & $\begin{array}{l}\text { Constant } \\
\text { coefficient }\end{array}$ & 2.356 & 3.981 & 0.000 & 2.351 & 2.321 & 0.031 & 2.317 & 2.563 & 0.022 \\
\hline & $\Delta(\triangle \mathrm{REV}-\Delta \mathrm{AR})$ & 0.586 & 2.328 & $0 / 025$ & 0.486 & $2 / 172$ & $0 / 033$ & 0.365 & $2 / 596$ & $0 / 011$ \\
\hline & PPE & 0.545 & $2 / 127$ & $0 / 037$ & 0.175 & $2 / 632$ & $0 / 01$ & 0.255 & $2 / 161$ & $0 / 034$ \\
\hline & ROA & 0.852 & $2 / 448$ & $0 / 017$ & 0.265 & $2 / 641$ & $0 / 012$ & 0.487 & $1 / 553$ & $0 / 121$ \\
\hline & $R^{2}$ Adjusted & 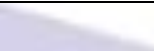 & $\% 22$ & & 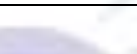 & $41 \%$ & & & $31 \%$ & \\
\hline & F-statistic & & 7.354 & & & 12.021 & & & 10.842 & \\
\hline
\end{tabular}

\subsection{Testing of hypotheses}

Significance of mean difference of accruals quality and volume of abnormal accruals in different stages of life cycle has been studied in Tables (6) and (7) using t-test.

\subsubsection{Testing secondary hypothesis 1}

In order to test the secondary hypothesis 1, the statistical hypothesis is explained as below:

HO: Means of accruals quality in different stages of life cycle (growth, maturity and decline) do not have a significant difference with each other.

$\mathrm{H} 1$ : Means of accruals quality in different stages of life cycle (growth, maturity and decline) have a significant difference with each other. 
Table 6. Mean of accruals quality in corporate life cycle stages

\begin{tabular}{|l|c|c|c|}
\hline \multicolumn{1}{|c|}{ Stages of corporate life cycle } & Number (firms-years) & Mean & Standard deviation \\
\hline Growth & 324 & 1.242 & 4.675 \\
\hline Maturity & 588 & 2.561 & 3.782 \\
\hline Decline & 408 & 1.982 & 2.965 \\
\hline F-statistic 9.451 & \multicolumn{2}{|c|}{ significance (P-value) 0.0021} \\
\hline
\end{tabular}

According to Table 6 , results of $\mathrm{F}$ test for comparing mean values of accruals quality in growth, maturity and decline stages show that mean difference of accruals quality at different stages of the corporate life cycle is significant at confidence level 95\%; because F-statistic (9.4516) is more than the minimum acceptable value for confidence level $95 \%$. As a result, the statistical assumption regarding significant difference of accruals quality among the firms at growth, maturity and decline stages is not rejected at the acceptable error level $5 \%$. Therefore, secondary hypothesis 1 is confirmed. Given to results of Table 6, it can be stated that accruals quality (financial reporting quality) is at the highest level in maturity stage; while it is at the lowest level in growth stage.

\subsubsection{Testing secondary hypothesis 2}

In order to test the secondary hypothesis 2 , the statistical hypothesis is explained as below:

HO: Means of volume of abnormal accruals in different stages of life cycle (growth, maturity and decline) do not have a significant difference with each other.

$\mathrm{H} 1$ : Means of volume of abnormal accruals in different stages of life cycle (growth, maturity and decline) have a significant difference with each other.

Table 7. Mean of volume of abnormal accruals in corporate life cycle stages

\begin{tabular}{|l|c|c|c|}
\hline \multicolumn{1}{|c|}{$\begin{array}{c}\text { Stages of corporate life } \\
\text { cycle }\end{array}$} & Number (firms-years) & Mean & Standard deviation \\
\hline Growth & 324 & 1.312 & 6.972 \\
\hline Maturity & 588 & 0.824 & 4.612 \\
\hline Decline & 408 & 1.023 & 1.612 \\
\hline F-statistic 16.765 & & \multicolumn{2}{c|}{ significance (P-value) 0.000} \\
\hline
\end{tabular}

According to Table 7, results of $\mathrm{F}$ test for comparing mean of volume of abnormal accruals in growth, maturity and decline stages show that mean difference of volume of abnormal accruals at different stages of corporate life cycle is significant at confidence level 95\%; because F-statistic (16.765) is more than the minimum acceptable value for confidence level $95 \%$. As a result, the statistical assumption regarding significant difference of volume of abnormal accruals among the firms at growth, maturity and decline stages is not rejected at the acceptable error level $5 \%$. Therefore, secondary hypothesis 2 is confirmed. Given to results of Table 7, it can be stated that financial reporting quality (volume of abnormal accruals) is at the highest (lowest) level in maturity stage and is at the lowest (highest) level in growth stage.

\section{CONCLUSION}

Financial reporting quality can affect investors' trust in financial markets. Researchers have discussed about financial reporting quality during the three recent decades and it has been tried to evaluate financial reporting quality through achieving a logical and reliable method and identify the effective factors on it. The conducted researches in other countries such as Anthony and Ramesh (1992), Black (1988), Aharoni et al. (2003) and Xu (2007) indicate the important effect of life cycle on accounting variables. Financial reporting quality is one of the most important accounting information. Results of data analysis related to 110 firms (1320 firms-years) during the time period 2002 2013 show that accruals quality and volume of abnormal accruals (indexes to evaluate financial reporting quality) in different stages of corporate life cycle (growth, maturity and decline) have a significant difference with each other. Financial reporting quality, thus, is at the highest level in maturity stage and the lowest level in growth stage. Considering the results of the present study, it is suggested to activists of the capital market, decision-makers, financial analysts and potential and actual investors of the stock exchange to pay special attention to the effect of 
corporate life cycle on financial reporting quality in analysis of investment plans in financial assets and securities. The reason is that the optimal portfolio with minimum risk and maximum return can be selected considering these important factors. Moreover, transparency of decision-making environment and the obtained results will be enhanced.

\section{Acknowledgement}

Author want to thanks Dr.Sadr Ara for their kindly remarks during this research.

\section{REFERENCES}

[1] Adizes, I. (1989). "corporate life cycle: How and Why corporations Grow and Die and What Do about it", Englewood Cliffs, NJ

[2] Aharony, J., H, Falk and N, Yehuda,(2003). "Corporate Life Cycle and the Value Relevance of Cash Flow versus Accrual Financial Information" , School of Economics and Management Bolzano, Italy, Working Paper No. 34

[3] Anthony, J. H. and Ramesh, K. (1992,2001). "Association between accounting performance measures and stock prices: A test of the life cycle hypothesis" , Journal of Accounting and Economics ,Vol. 15, pp. 203227.

[4] Black, E.L. (1998). " Life-cycle impacts on the incremental value-relevance of earnings and cash flow measures", Journal of Financial Statement Analysis, Vol. 4, pp. 40-56.

[5] Dehdar, F. (2008). Proposing and explaining superior models of valuation based on accounting earnings and cash flows in the process of corporate life cycle (Doctoral dissertation, Tarbiat Modares University)

[6] Jenkins, D.S., Kane, G.D. and Velury ,U.(2004)."The impact of the corporate life-cycle on the valuerelevance of disaggregated earnings components ", Review of Accounting and Finance, Vol. 3, pp. 5-20.

[7] Kallunki ,J. ,Silvola , H. (2012). " The effect of organizational life cycle stage on the use of activity-based costing", Management Accounting Research Vol.19, pp.62-79.

[8] Karami, GH.; Omrani, H. (2011). The effect of corporate life cycle on conservatism and corporate value. Journal of Accounting and Auditing Studies, 59, 79-96

[9] Khosravi, V. (2010). Comparing financial information based on cash flows and financial information based on accrual accounting in stock return prediction given to corporate life cycle (Master's thesis, Islamic Azad University, Neishabour branch).

[10] Muller, D.C.(1972). "A Llife Cycle Theory of Firm", Journal of Industrial Economics20, pp.199-219

[11] Thanatawee, Y. (2011). Life-cycle theory and free cash flow hypothesis: Evidence from dividend policy in Thailand . Journal of Business, Vol.34:pp. 411-433.

[12] Troung, T. and R. Heaney (2007). Largest shareholder and dividend policy around the world, The Quarterly Review of Economics and Finance, vol.47pp.667-687.

[13] Vuong, Quang H.(1989). "Likelihood ratio tests for model selection and non-nested hypotheses", Econometrical 57, pp.307-333.

[14] Wang ming-hui, day- yang liu, (2009). Dividend policy and the life cycle hypothesis, www.ssrn.com.

[15] Xu, Bixia.(2007). "Life cycle effect on the value Relevance of common risk factor " , Review of Accounting and Finance Vol.6, pp.162-175. 